\title{
Decay of Traditional Ecological Knowledge and Ethno Medicine: A Study In Joypur Jungle Mahal, Bankura District, West Bengal.
}

\author{
Sarbajit Kumar Ghosh ${ }^{1}$, Dr. Sanat Kumar Guchhait ${ }^{2}$, Shyamal Santra ${ }^{3}$. \\ ${ }^{1}$ (Research Scholar/ Department of Geography, University of Burdwan, India) \\ ${ }^{2}$ (Associate Professor/Department of Geography, University of Burdwan, India). \\ ${ }^{3}$ (Assistant Teacher/ Joypur High School, Bankura, West Bengal, India).
}

\begin{abstract}
Irrational exploitation of Nature and Natural Resources are plundering our natural system, jeopardizing the ability of the system to bounce back to its previous condition. Due to human intervention feedback mechanism of the natural system is decaying rapidly, at the same time indigenous societies are distancing from the wild ecology which is proving to bear a detrimental effect upon their socio economic fabric. Globalization and tecnocentrism has radically changed their web of relationship between wild ecology and tribal society. Folk medicinal knowledge and the abundance or extinction of medicinal plants may serve as a missing link to conceptualize ecology, economics, ethics and folk society under study and the change scenario. A proper assessment of knowledge on ethno medicine will help to conceptualize the changed scenario and promote reasonable measures to sustain the medicinal valued plant species and socio ecological sustainability.
\end{abstract}

Keywords: decaying, ecological sustainability, ethno medicine, indigenous society. wild ecology.

\section{Introduction}

Like numerous tribal societies the Sari Dharam people of Santal community in Joypur Jungalmahal have a vast archive of traditional ecological knowledge about the Nature and natural resources surrounded there in as they live in close proximity to nature .Their traditional life system have a close and intricate relationship with nature.. Their view is essentially eco centric. Ecocentrism can be ascertained in their attitude towards plants, animals and the earth. Traditional Ecological Knowledge (TEK) of those forest people relating to preservation of habitat and conservation of ecology and sustainable resource management has a great potential value for the present society as well as well for the future generation. Cognitive environmental knowledge among the rural people especially tribals, concerning useful medicinal plants are helpful for conservation of cultural heritage of the tribal people and in situ biodiversity preservation. The objective of the present study is to interact with the traditional dwellers of Joypur Jangalmahal; Bankura district, gleaning out their wealth of knowledge about their ecological understanding about the medicinal plants in order to conceptualize their environmental perception as well as social sensitiveness.

\section{Ethno Medicine Defined}

Ethno medicine essentially refers to beliefs and practices of traditional societies relating to application of medicinal plants to cure various diseases which are the products of indigenous cultural development and not explicitly derived from the framework of modern science.

Ethno medicine is essentially concerned with looking at the dynamics of relationship between traditional societies (sociopolitical, ethical \& economic dilemmas) on the one hand and between various medicinal plant species, population, landscape and ecosystem on the other hand. Until such issues are amply discussed and fairly resolved the research runs on ethically questionable issues. Ethnomedicine of the tribals has essentially very little to do with medicine as everybody ordinarily understands this term, for the tribals do not share the understanding of disease processes as defined by modern medicine. For them medicine is asocial institution enhancing every aspect of individual security-psychological, physical and social. People in modern society view medicine as a branch of science engaged in diagnosis, treatment and prevention of disease. It has no interest in the morality, social status and religious life of the patient. It views disease as a natural phenomenon and suggests natural remedies for it.[1]

Ethical. [2]

The benefits accruing from this knowledge are-(1) Economic, (2) Social, (3) Ecological \& (4)

(i) Economic aspects-Medicinal plants harvested from the forests have huge financial implication. Apart from this medicinal plants have become a globally contentious issue in recent time.

(ii) Ecological aspect- Relates to manipulation of biodiversity for combating with uncertainties in the environment \& global change.

(iii) Social Aspects- Traditional societies making a distance with the eco-centric framework of life. 
(iv) Ethical aspects- Cultural and religious belief around the concept of medicinal plants

\section{A glimpse of the environment and the people of the study area}

Joypur forest is a dense mixed forest dominated by Sal (Soria Robasta) with a huge number of herbs and shrubs some of which are used as by the local people as medicinal plants. It is a well known forest in West Bengal with wider forest coverage in the western part of the Joypur block located at the SE corner of Bankura district, West Bengal. The forested areas have the extension of between $22^{\circ} 59^{\prime} 40^{\prime \prime}$ north and $23^{\circ} 05^{\prime} 52^{\prime}$ ' north and between $87^{\circ} 23^{\prime} 8^{\prime}$ 'East \& $87^{\circ} 27^{\prime} 40^{\prime}$ 'East. The Climate in the upland tracts in the west is much drier than the eastern parts. The total annual rainfall is $1400 \mathrm{~mm}$ ( 55 inch) most of which occurs in Monsoon period (June to September). From the beginning of March upto June, hot westerly winds blows. Temperature rises to around $45^{\circ}$ $\mathrm{C}$ in May. Winter is much cooler where temperature drops down below $10^{\circ} \mathrm{C}$.Forest area is nourished by laterite soil and not conducive for agriculture for its low fertility level. Altogether 19 villages are located within the forested track where the people mainly belonging to Santal community are habituated to lead their livelihood mainly from the forest resources. They collect the drinking water from underground which is enriched by iron. The groundwater is also contaminated by microbes which is responsible for Jaundice.

\section{Material and methods}

An empirical survey was undertaken to collect the information about the medicinal plants used by the three villagers named Murabari Namopara, Murabari Majhpara and Natungram in Joypur Jungalmahal. The informants were asked to go to the field and identify the plant species. Then herbarium were prepared and later taxonomically identified. The pre defined and pre tested questioner also incorporated relevant social, economic questions to highlight the dynamic relationship between the trio economy-culture-society.

\section{Historical Context}

Ethno medicine essentially deals with species collected from the wild and used by the traditional societies. There is much accumulated ancient literature of descriptive nature on the food and medicinal plants used by the traditional societies form different parts of the world. We do not know exactly when the uses of medicinal plants were started but undoubtedly it is a stream of knowledge coming down from generation to generation. Plants were classified and studied according to their quality and action during the Vedic period. We got this evidence from 'Osadhi Sukta' of Rig Veda.(10.97. 1-23).[3] According to one story of Caraka Samhita this knowledge started from Brahma and passed through Daksha Prajapati and Indra to Bhardwaya or Atri who handed it down to Atreya. From Atreya this knowledge spread to different parts of India and absorbed by his countless students. We get some evidences from Rigveda that the medicinal plants played vital role in the contemporary society. Reverend Bodding in his famous book titled 'Studies in Santal Medicine and connected Folklore' documented about the medicinal practices by the Santal folk therapists. Ethno medicinical study is not new to the academic discipline in India because it has a reach ethnic diversity. During the last few decades there is a growing interest in this discipline. Some of the important verses of Rgveda mentioned bellow speaks about the knowledge of ethno medicine in Vedic period which essentially triggers about the importance of medicinal plants in contemporary society.

$$
\begin{aligned}
& \text { avapatantīravadandiva os } \square \text { adhayaspari| } \\
& \text { yam jīvamaśnavāmahai na sa vis } \square \text { yāti purus } \square \text { ah } \square \| \\
& \text { R } \square \text { gveda x.97.17. }
\end{aligned}
$$

The plants descending from heaven, said, no evil shall befall a man. Whom, while he lives, we nourish.(17)

$$
\begin{array}{r}
\text { Yā os } \square \text { adhīh } \square \text { somarāñjirbahvih } \square \text { śatavicaks } \square \text { an } \square \bar{a} h \square \mid \\
\text { Tāsām tvamsyuttamāram kāmāya śam hr } \square \text { de } \| \\
\mathrm{R} \square \text { gveda x.97.18 }
\end{array}
$$

Of all the plants, which have divine elixir, the master cure, for their king, which are numerous and all seeking, you, $\mathrm{O}$ divine elixir, are the best, be promt to the wishful and sweet to the heart.(18)

$$
\begin{gathered}
\text { Yā os } \square \text { adhīh } \square \text { slomarāñjīrvis } \square \text { th } \square \text { itāh } \square \text { pr } \square \text { thivīmanu| } \\
\text { br } \square \text { haspatiprasūtā asyai sam data bīryam\| }
\end{gathered}
$$

$$
\mathrm{R} \square \text { gveda.x.97.19 }
$$

May the plants which have the divine elixir, the Master cure, for their king, which are scattered all over the earth, which are the offspring of our supreme Protector, give vigour to this infirm body.(19).

os $\square$ adhayah $\square$ sam vadante somena saha rāñjā

yasmai $\mathrm{kr} \square \mathrm{n} \square$ oti brāhman $\square$ astam rājan pāvayāmasi $\|$ 
$\mathrm{R} \square$ gveda.x.97.22

All the plants in the presence of the divine elixir, the king, declare, O'King, we save him who on the advice of the expert physician, takes us as medicine (22).

With regard to the use of plants, as found in the Satapatha, it appears that many plants like Apamarga ( Lat. Acahyranthes aspera), Asmagandha ( Lat. Acacia catechu), Bilva ( Lat. Aegle marmelos), Varana ( Lat. Crataeva nurvala) etc were commonly used in the Brahmanic period and their efficacy was known to then society. [4]

\section{Traditional Wild Ecological Knowledge And Environmental Cognition}

Environmental perception and ethics towards wild ecology and ethno medicine are essential to the traditional societies because cultural landscape here is basically analogous to ecological landscape. It will act as an umbrella so as to avoid any drastic changes in their traditional living system. Also maintenance of soil fertility, nutrient cycling are embedded in their attitude which essentially emanate from their environmental perception. As traditional people are deeply integrated and ingredient with the wild ecology, such a positive outlook will allow the ecosystem to function properly where not only physical system but also social institutional parameters of sustainability is strengthened for ages.

The indigenous people under present study conceptualise the concept of illness with their age long experience through forest interaction that is now a lost of waylaid detached herbal plants. They perceive that these plants cured many ailments when they walked with barefoot over them. They perceive that the disappearance of pure soul residing in the medicinal plants is responsible for curing several pathological diseases. This symbolic power of the image arises from their daily travel along forest land and running through the Joypur Jangalmahal .Still the traditional religious beliefs prove their capacity for survival and self reassertion in the course of time. Like the tenacity of the traditional beliefs resting on premodal needs, the tenacity of traditional beliefs rests on needs to be in contact with the sacred. [5].

\section{Location Map Of The Study Area}

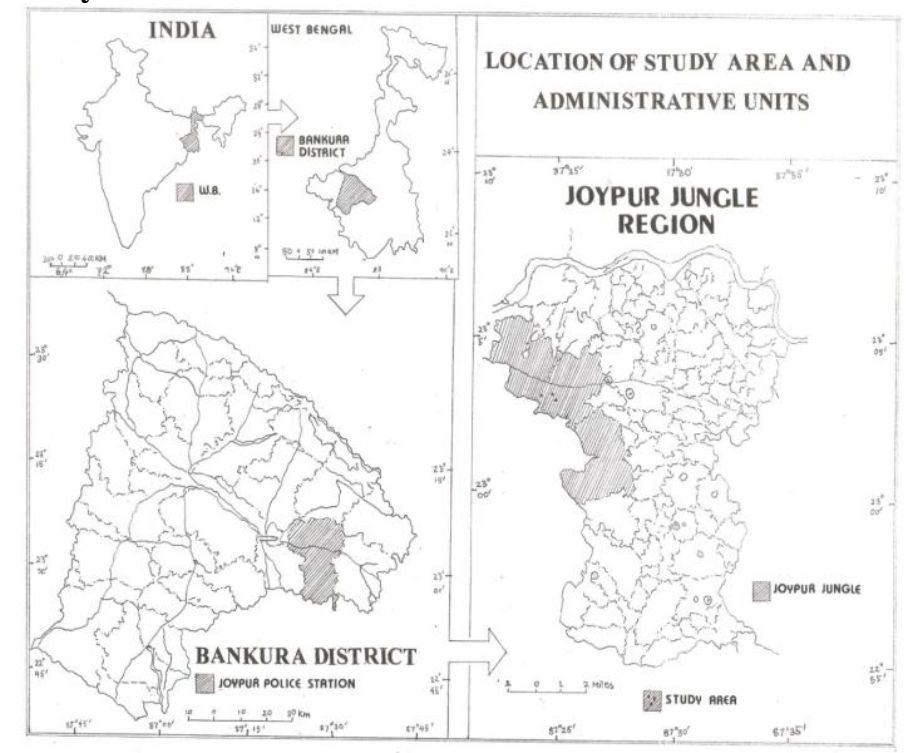

Fig.1

\section{Seasonal Diseases}

The chronic diseases which are prevalent in this area are jaundice, typhoid, and whooping cough Mumps, typhoid fever. Except the first one mainly Childs are the victim of attacks. From new born to old age, jaundice affects all age group. From our study percentage of jaundice infection was found highest in 30-45 year age group (49.25\% affection). While in case of new born babies (3-12 monts of age) the figure of affection is also high.33.33\% are affected by jaundice. Most of the incidence of affection occurs in pre monsoon period.

\section{Medicinal plants used by the study tribals in Joypur Jungle Mahal}

The results of the survey are presented in the following table comprises plants of ethno medicinal importance used by the study people. For each species botanical name, family local name and ailments treated are provided. Traditional people are using these plants to cure diseases related to skin problems, cold, cough, headache, wounds, diabetes, asthma, bone fractures and poison (snake, scorpion and insect bites). The study 
tribal people both men and women believe that these plant based medicines are easily available, inexpensive and with no side effect. Another reason for using medicinal plants by the tribal people is that they are simple living, poor and cannot afford synthetic drugs and their knowledge about ethno medicine has been passed from their antecedents for generation. The table given bellow shows some important medicinal plants used by the study tribals.

\begin{tabular}{|c|c|c|c|}
\hline $\begin{array}{l}\text { Bengali name } \\
\text { Tulsi }\end{array}$ & $\begin{array}{l}\text { Scientific name } \\
\text { Ocimum sanctum }\end{array}$ & $\begin{array}{c}\text { Family } \\
\text { Lamiaceae }\end{array}$ & $\begin{array}{l}\text { Uses } \\
\text { caugh, asthma, digestive trouble } \\
\text { blood sugar. }\end{array}$ \\
\hline Dhatri/Amlaki & Phyllontus emblica & Euphorbiaceae & liver tonic, acidity, sleeplessness. \\
\hline Basak & Adhatoda yasica & A canthaceae & Asthma cold and cough. \\
\hline Anantamul & Hemidesmus indicus & Asclepiadaceae & Diuretic, Urinary disease, bronchial trouble. \\
\hline Somancha & Citrullus vulgaris & ucurbitaceae & Typhoid, jaundice, headache. \\
\hline Sarpagandha, & Ranvolfia sarpentina & Apocynaceas. & hypertension and antidiabetic. \\
\hline Ghritakumari & Aloe yera & I liaceae mm & liver tonic, spleen ailments and pain. \\
\hline Kalkasund & Cassia sophera. & Leguminosae & hepatitis trouble, dysentry cough. \\
\hline Lajjabati & Minesa pudica & Leguminosae & Urinary trouble, simus \& piles. \\
\hline Kantakaria & Solanum Xanthocerpum & Solanaceae & cough, asthma, liver trouble, dental disease \\
\hline Akandi & Calotropis procera & Asclepiadaceae & leprosy, eye trouble, digestive problem. \\
\hline Satamuli. & Asparagus racemosus & Liliaceae & blood dysentry, phyleria nyctapols. \\
\hline Indrajab & Hollarrhena antidusentrica & Apocynaceae & dysentry, fever. \\
\hline Siuli & Nictanthes arbortristis & Oleaceae & Fever, arthritis, sciatic pain. \\
\hline Salparmi & Desmodium gangecticum & Leguminasae & Pain, caugh, gland. \\
\hline Olatkambal & Abromoma angugusta & Sterculiaceae & Uterine tonic, Neuralgia. \\
\hline Aiapan & Patorium triplinerve & Compositae & Haemostatic, low pressure. \\
\hline Ghentu & Clerodenaton yiscosum & Verbenaceae & Colic pain, malaria, louse, skin problem. \\
\hline Harjora & Cissus Quadrangulas is & vitaceae & Healing fractured bones (Reported). \\
\hline
\end{tabular}

IX. Magico - Religious Practices -An Attempt To Stick To Herbal Medicine

Sometimes folk therapists are associated with rituals and beliefs. It is essentially a cultural system to look into linking local pattern of meaning, power and social interaction. This is normally done by the spiritual healers. The study reveals that certain diseases are caused by malevolent super power such as mental morbidities specially. The study villagers propitiate various gods and goddess in their own way. In case of snake biting they go to the Ojha. Ojha is a Hindi word ; in Hindi it is used for ' a diviner, soothsayer, wizard, enchanter, conjurer, exorcist, magician;- one who pretends to cast out evil spirits, to cure snake bite, etc by means of charms and incantations. The old idea of deriving the word from Hindi ojh, entrails, comprising Ojha with the Latin haruspex, is likely abandoned. [6] .In case of severe ailment they visit to the Thakurbari (Dumouni and Laugram Kalimandir) where the praists perform some magico religious practices. The ceremonial performances link the ill person and sprit guide, which transform the dreamer into a medium for the spirits to diagnose and treat illness. They use several herbal plants during the course of treatment. The magico religious practices is an attempt to weaken the mind of the patient such that he totally belief on Ojha. A Santal Ojha is supposed to be able to perform certain things that are outside the knowledge and power of ordinary people. By this way he will maintain all the dictums of Ojha properly and thus take the medicines accurately. So magico religious practices are nothing but psychological treatment \& herbal medicines are physiological treatment. They suppressed the names of herbal plants to the common people to avoid bio piracy as well as the preservation of medicinal and herbal plants. The tribals prefer to use the therapeutic measures of their Ethnomedicine when affected with maladies which have been traditionally present in their community and they seek modern medicine only for the newly imported diseases. They also believes that the modern medicine cures only the symptoms of disease and that the underlying causes can be eradicated only with the help of shaman. So, even if the patient is undergoing treatment the shaman must be approached to get a complete cure. It is common practice that a patient who takes modern medicine also goes to temple and makes offerings to god .

\section{Raisons de etire of decaying}

The ground truth reality experienced through field survey must be unfolded here to justify the essence of the paper. The quality of life has improved to some extent for the tribal people in West Bengal. At the same time, Joint Forest Management (JFM) has drastically reduced the diversity of ecosensitive species in the forest area enriched with medicinal plants. Now selected woodlots (profit making trees) are allowed to grow at the cost of other beneficial herbs and plants. People have to work hard to find out popular medicinal plants which were highly available earlier. So likely they are gradually intending towards popular synthetic drugs and their knowledge about herbal medicines is gradually decaying day by day. As the tribals do not have the habit of growing medicinal plants for their needs, they have always dependent upon natural sources. When the natural sources are destroyed they find it difficult to collect the various essential ingredients of medical preparations. This equally applicable in case of animals also. They used to mix a number of animal matter as ingredients of medicine. 


\section{Medicinal plants less abundant now:}

The medicinal plants which were abundant in the forest areas like,

Bishalakarani (Justicia gendorussa) acanthaceae family, Aiapan (Eupaterium triplirve) Compositae family, Amlaki (Emblica officinalis), Swet Belara (Sida Cordifolia) Malvaceae family), Satamuli (Asparagus recemosus) Liliaceae family, .Pudina (Mantha piperita/Mantha spicatal, Mantha arvensis/ Mantha citrota) lamiaceae family, Sarpagandha (Rauvolfia serpentine) and Anantamul (Hemidesmus indica) are now rarely found in this area. Among them Pudina, Bishalakarani have almost disappeared from the Joypur forest. Irrational exploitation and extraction of whole plant species rather than the extraction of medicinal important parts are the root cause behind the abolition and marginalization of these medicinal important plant species from the study area.

\section{Tragedy of JFM for decaying of Traditional Ecological Knowledge}

A significant step towards protection of forest in the Joypur Jangalmahal is the launching of Joint Forest Management (JFM) and formation of FPC (Forest Protection Committee) in 1994. It aimed to activate the participation of people living in the forest $\&$ fringe areas of the Jungle to bear the long term conservation and utilization goal. Before 1994 household income of the tribals of the said forest area comprised entirely upon the forest products. Handicraft of low grade, mainly Jhanta making, selling of Shal leaves and making of thali (tray) from Shal leaf comprised a major source of income to the study people.

Bamboo grooves were plentiful in the forest but after the strict imposition to exploit Bamboo trees from the forest came as a stroke to their income. The Forest Department afterwards also did not take any initiative to plant Bamboo grooves in the forest. The policy has led to almost total disappearance of this groove from the forest. The Simple input output cost keeping aside the aesthetic input on society (Which cannot be judged by such commercial calculation) shows that their economy felt in a state of absolute crisis which despite of $25 \%$ share of JFM failed to supplement.

\begin{tabular}{|l|}
\hline TABLE 2.STATUS OF FOREST \\
PREOTECTION COMMITTEE IN \\
JOYPUR JUNGLEMAHAL \\
1. Total Forest area-619900 hec \\
2. Forest Committee -52 \\
3. Members -5217 \\
4. Female members-156 \\
5. Scheduled Caste -2751 \\
6. Scheduled tribe -229 \\
7. Others 2237 \\
\hline
\end{tabular}

The Sari Dharam people under study have a low value of closed economy with a low value of technological input. They practice monoculture, paddy only in the rainy season. A considerable proportion of families in the study Villages are landless. In Murabari Majhpara 8 (out of 25families), Murabari Namopara 9 (out of 19) and Natungram 7 (Out of 19families) are found landless. Majority of land holders possess within 5 10 Katha ( Katha is a measure of land which equals to720 Sq. feet, 1/20 of Bigha) of land which was distributed mostly after the enactment of Tribals and Other Forest Dwellers Act 2009. From table 2 \&Figure 2 it is very true that Membership of FPC (Forest Protection Committee) is accuring benefit but the people .Out of Forest Protection Committee (near about $60 \%$ of the surrounding household) who would earn a considerable amount of their resource are completely out of the Laxman bar created by JFM Committee. Their sufferings are not being accounted either economically or socially. Rather success of JFM is widely accepted throughout the world. At the same time this JFM programme has created a wall in relation to traditional forest -tribe interaction. Development and to some extent modernism have widened this forest- tribe interaction more severely. This is basically responsible for decaying Traditional Ecological Knowledge \& Ethnomedicine. 
TABLE 3: EARNING FROM THE SHARE OF MEMBERSHIP OF FOREST PROTECTION COMMITTEE

\begin{tabular}{|l|r|r|r|r|}
\hline Year & Amount(Rs) & Person & $\begin{array}{c}\text { 3 Year Moving } \\
\text { total (Rs) }\end{array}$ & $\begin{array}{c}\text { 3 Year Moving } \\
\text { Average (Rs) }\end{array}$ \\
\hline $1995-' 96$ & $5,86,918$ & 86 & & 428524 \\
\hline $1996-' 97$ & $6,28,093$ & 75 & 1285574 & 416590 \\
\hline $1997-' 98$ & 70,563 & 75 & 1249770 & 399646 \\
\hline $1998-' 99$ & $5,51,114$ & 75 & 1198938 & 737529 \\
\hline $1999-2000$ & $5,77,261$ & 75 & 2212589 & 848393 \\
\hline $2000-' 01$ & $10,84,214$ & 75 & 2245180 & 1074100 \\
\hline $2001-' 02$ & $5,83,705$ & 75 & 2674351 & 1886626 \\
\hline $2002-' 03$ & 1006432 & 88 & 3222301 & 2228118 \\
\hline $2003-' 04$ & 1632164 & 88 & 5659879 & 1960032 \\
\hline $2004-' 05$ & 3021283 & 88 & 6684356 & 2986786 \\
\hline $2005-' 06$ & 2030909 & 88 & 8334609 & \\
\hline $2006-' 07$ & 3282417 & 92 & 5880098 & \\
\hline $2007-' 08$ & 566772 & 92 & 8960359 & \\
\hline $2008-' 09$ & 5111170 & 92 & & \\
\hline
\end{tabular}

\section{Source: Beat office, Joypur}

The above policy document asserted that local people have been energized towards the development and protection of forest from which they accure benefits. Non wood forest products (NWFPs) have a key role in this effort. The forest protection committee members have become entitled from these benefits including collection of Non wood Forest Products (NWFPs) and 25\% share of profits of lumber cutting by the Forest department. As per directive principles of FPC \& EDC formation, participation of women, SCs and STs have been ensured as evident from the data above.

\section{JFM And Forest Protection Act (FPA)- An Early Shock To The Tribal People}

Before the introduction of forest the villagers used the forest extensively ranging from collection of fruits, timber (mainly Soria robasta), buffer areas as foraging and ranch field for their cattle. The enactment of FPA begirded their economy. After JFM was introduced 12 families migrated from the villages (4 from Natungram, 1 from Babudanga, 2 from Namopara, 3 from Majhpara \& 2 from Sadhpukur) as they faced starved due to banning the forest for exploitative use.

\section{Erosion of traditional knowledge}

The knowledge of medicinal plants among the traditional people in this area is based on hundreds of years observations. This knowledge has been transmitted orally from generation to generation. Frequently today we highlight the ecological people, those who have close connection with nature, who collect their basic resource from nature. Tribal people close to forest or natural ecosystem belongs to the category. Between the physical environment and human activity there is always a cultural pattern. Physical conditions enter immediately into every cultural development and pattern not excluding the most abstract and non material. They entre not as determinants, however, but as one category or raw material of cultural elaboration [7]. The survey reveals that the younger generations are not very much interested about the indigenous method of treating ailments. They even are not very conscious about the importance of these medicinal plants and their potential medicinal value. One Medicine man from Namopara named Biswanath Soren regrated to the authors that his son is not very much interested in this practice as it has very low potential income. The growing disinterest in the use of medicinal plants and its uses may eventually lead to the disappearance of ethno medicinal practices in the near future. Younger generation should be motivated to protect and cultivate these valuable species before they totally get disappeared from this area. Traditional medical knowledge of medicinal plants and their use by the indigenous culture are not only useful for conservation of cultural traditions and biodiversity but also for community healthcare.

\section{Reasoning Behind In-Situ Preservation}

Bio- technology based on ex-situ conservation and manipulation of wild species especially medicinal species is highly cost effective; preservation of the germplasm of essential herbaceous species also cannot give the desired result. Under given location specificity, pedogenic condition and under allied physical conditions the medicinal qualities of the botanical plants are highest. So the issue of maintaining wild ecology in the context of preservation of ethno medicine has to be looked from this perspective. Such a shift in ecological perspective could form the basis for maintenance of wild ecology and preservation of ethno medicinal plants in situ. 


\section{Conclusion}

The present study clearly indicates that, the study area has plenty of medicinal plants which have a huge potential to treat a wide spectrum of human ailments. Due to lack of interest of young generation there is every possibility of erosion of this vast wealth of knowledge in the near future. It has thus become necessary to accure and preserves this traditional system of medicine by proper documentation and identification of species.

After introducing the rational \& assessment method for the current study, the report explains how such an analysis can help building a sustainable future prospect for the study people. Sustainability essentially lies in the juxtaposition of the three pillars namely economy, society and environment where there is absence of any conflict between them. Rise of any conflict will eventually destroy the buffering capacity of the ecosystem. Massive eco destruction will jeopardize the ever balancing delicate relationship between the traditional social fabric and nature. We must not forget the fact that just one cell is part of the living body similarly every community is the integral part of global cultural system especially in the context of cultural fusion where tribal culture, knowledge, customs, resources are gradually incorporated in civil society.

Proper valuation of the Traditional Ecological Knowledge (TEK) would work towards a better conceptualization and management of wild ecology, preservation of ethno medicine as well as sustainable societal development for the indigenous population under study. Technologically managed ecosystem restoration can only achieve some short range solution, cannot pave way for their sustainable development. Proper \& justified way to understand wild ecosystem is to work with the knowledge system of the traditional people, i.e, what the local communities comprehend and appreciate. Their perception is intermingled with ecological and social system (holistic ecology) that is essentially in the state of absolute harmony. So the study of ethno medicine essentially triggers to the traditional wisdom of the indigenous people, they carry, or the verge of extinction, or they have already lost. Such an analysis will provide an inventory to the maintenance and management of essentially important herbaceous species and dynamic study of socio ecological integrity.

\section{Acknowledgements}

The authors are thankful to all respondents of the study villages for their cooperation during the field trip. The authors also thankful to Dr. Mohan Lal Ghosh, Reader and ex Head of the Department of Botany, Bijoy Narayan Mahavidyalaya, Itachuna, Hooghly and late Ranjit kumar Ghosh for their contribution.

\section{References:}

[1] Jose Boban K, Tribal Ethnomedicine: Continuity and Change (A.H.P Publishing Corporation, New Delhi, 1998) 136,137

[2] P.S.Ramakrishnan, Ecology and Sustainable Development (National Book Trust, New Delhi, 2001) 27.

[3] Swami Satya Prakash Saraswati, Satyakam Vidyalankar, Rigveda Samhita xiii (Veda Prakashan, New Delhi, 1987)1-23.

[4] Mridula Saha, History of Indian Medicine Based on Vedic Literature Satapatha Brahmana (The Asiatic Society, Calcutta, 1999) 31.

[5] Sankar Sen Gupta, Sacred Trees Across Nation and Culture ( Indian Publications, Calcutta,198 P.O.Bodding, Studies in Santal Medicine and Connected Folklore (The Asiatic Society, Kolkata, 2001) 57

[6] P.O.Bodding, Studies in Santal Medicine and Connected Folklore (The Asiatic Society, Kolkata, 2001)10,11.

[7] Eco Culture in S.P.Sharma and J.B Sharma (Ed), Culture of Indian Tribes (Radha Publications, New Delhi, 1998$) 343$. 